\title{
大容量超電導コイルのクエンチ時 温度上昇の解析
}

\author{
古戸 義雄, 井上 至*, 三好 一富** \\ 松本 要林*，田中 靖三*** \\ 古河電気工業釈研究開発本部 横浜市西区岡野 2-4-3 \\ * 古河電気工業梿新機能製品事業部超電導製品部 日光市清澺町 500 \\ ***古河電気工業侏新機能製品事業部超電導製品部 市原市八幡海岸通 6 \\ *** 古河電気工業的横浜研究所 横浜市西区岡野 2-4-3
}

(1993 年 4 月 30 日受理)

Analysis of the Temperature-Rise in Large-Capacity

Superconductor Coils with Quenches Occurred

Yoshio Furuto, Itaru Inoue,* Kazutomi Mryoshi,**

Kaname MATSUMOTO*** and Yasuzo TANAKA***

The Furukawa Electric Co., Ltd., R \& D Division, 2-4-3 Okano, Nishi-ku, Yokohama 220

* The Furukawa Electric Co., Ltd., New Function Products Division, 500 Kiyotaki-cho, Nikko 321

** The Furukawa Electric Co., Ltd., 6 Yahata, Kaigan-dori, Ichihara 290

*** The Furukawa Electric Co., Ltd., Yokohama Laboratory, 2-4-3 Okano, Nishi-ku, Yokohama 220

(Received April 30, 1993)

\section{Synopsis :}

Considering both self-heating of the normal zones propagating in coils wound with largecapacity superconductors and power consumption by external resistors, we have analyzed the temperature-rises in the coils and deduced new analytical formulas by introducing effective decay time constants and by considering energy-balancing in the system. Calculations by using this formula and computer simulations were conducted for small-scaled SMES coils wound with $20 \mathrm{kA}$ superconducting cable conductor and comparison was made between these results. It was found that our formula gave a temperature-rise higher by about twenty percents than the computer simulation result, while Wilson's formula gave a temperature-rise much higher than ours and of too safety side. It has been demonstrated that the formula is physically more reasonable and practical than Wilson's. However, the formula is more limited than computer simulations in taking-in of rigorous temperature-dependence of various properties and in dealing with complicated propagations of normal zones, so computer simulations are desirable for us to get more real temperature-rises to be expected in the coils.

\section{1. 序論}

超電導マグネットはクエンチを起こすと, 蓄積エネ ルギーか常電導部で消費され, 時には過大に温度上昇 し燒損してしまうことがある。このような事故を防ぐ ため, 種々のマグネット保護法が開発されている。マ グネット保護法は, 機能的に i ) パッシブ方式と ii) アクティブ方式に大別される。 広義のパッシブ方式には (1) 自己保護型がある。小
型マグネットの場合にはクエンチ時に常電導域が速や かに伝搬し, 常電導抵抗の増大により電流が急速に減 衰するので，保護対策は不要であり自己保護型と呼ば れる。典型的なパッシブ方式としては (2) 多分割保護 抵抗型と (3) 結合 2 次回路型があり, 中型マグネット への適用例がある。さらに蓄積エネルギーが大きく常 電導域が伝搬し難い大型マグネットの場合には, アク ティブ方式（スイッチ切換）の (4) 外部保護抵抗型を 採用するのが通例である。 


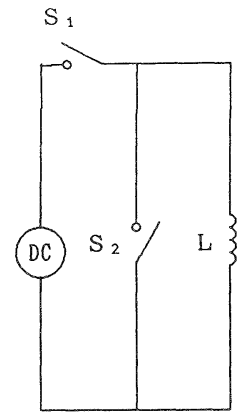

(a)

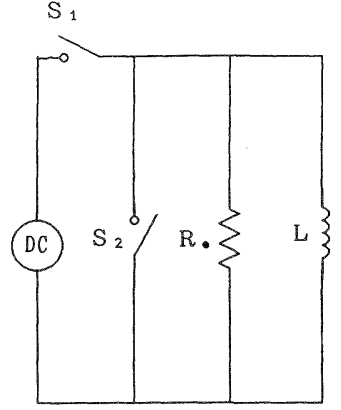

(b)

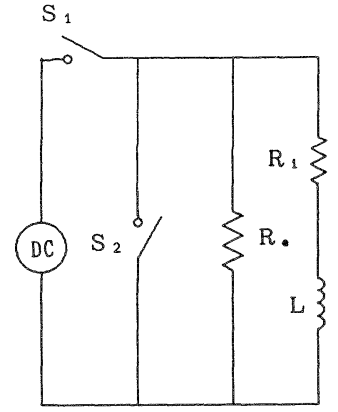

(c)

Fig. 1 Protection circuit of superconducting magnet. (a) $R=R_{\mathrm{i}}\left(R_{\mathrm{e}} \sim 0\right)$, (b) $R=R_{\mathrm{e}}\left(R_{\mathrm{i}} \sim 0\right)$, (c) $R=R_{\mathrm{i}}+R_{\mathrm{e}}$.

自己保護型の小型マグネット巻線のクエンチ時温度 上昇は, Fig. 1 (a) の常電導伝搬による内部抵抗 $R_{\mathrm{i}} に$ よって定まる(ケース a)。この場合の解析は, Wilson によって詳細になされ, 近似的解析法（ホットスポッ トモデル）として確立している1。一方，大型マグネ ット用導体は完全安定化あるいは Maddock 安定化モ ードで設計されるので, 常電導域の伝搬は 無 視でき $\left(R_{\mathrm{i}} \sim 0\right)$ 電流隇衰は外部保護抵抗 $R_{\mathrm{e}}$ に上り決まる (ケース $\mathrm{b}$ )。導体の温度上昇は, この時定数 $\tau=L / R_{\mathrm{e}}$ と比抵抗 $\rho$. 比熱容量 $\gamma C$ の 関数 $U(\theta)=\int_{4.2}^{\theta}\{\gamma C(\theta) /$ $\rho(\theta)\} d \theta$ により一義的に定まる。この中間の中型マグ ネットの場合には, 常電導伝搬による $R_{\mathrm{i}}$ の自己発熱 と $R_{\mathrm{e}}$ による消費を同時に考慮する必要があるが（回 路抵抗 $R=R_{\mathrm{i}}+R_{\mathrm{e}}$ ), このような複合的ケース $\mathrm{c}$ の解 析は未だなされていない。

ここでは, 新たに実効時定数を導入し, この時定数 により電流減衰が起こるとして, 常電導伝搬による自 己発熱と外部保護抵抗体消費の両方を考慮した複合的 ケースの実効減衰時間と導体温度上昇の解析式を導 く。Wilson にならって, 無制限伝搬と共に 1 次元〜 3 次元制限の場合の近似式を導出する。適用対象とし て小型 SMES 用導体を取り上げ, 本近似式を適用し て温度上昇解析を行い，計算機シミュレーション結果 と比較する。最後に, 本近似式と Wilson の近似式あ るいは簡便式との比較検討・考察を行うこととする。

\section{2. 前提条件と基本式}

Wilson は，下記の前提条件の下で自己保護型コイ ル巻線の温度上昇解析を行った。

(a) コイル電流密度 $J$ は, 全蓄積エネルギーがコイ

Vol. 28 No. 8 (1993)
ル中で消費されるまで一定であり，消費完了時に急に ゼロに降下する。

(b) 導体の温度上昇 $\theta$ および減衰時間 $T_{\mathrm{d}}$ は $\int J^{2}(T)$ $d T=J_{0}{ }^{2} T_{\mathrm{d}}=U(\theta)=\int_{4.2}^{\theta}\{\gamma C(\theta) / \rho(\theta)\} d \theta \simeq U\left(\theta_{0}\right)(\theta \mid$ $\left.\theta_{0}\right)^{1 / 2}$ によって与えられる $\left(\theta_{0}\right.$ : 基準温度)。

(c) 比抵抗 $\rho$ は, 温度に比例して増加する。

我々は，上記(b)および(c)の条件は踏襲するが，(a)の 条件を次のように修正する。

$\left(\mathrm{a}^{\prime}\right)$ コイル電流密度 $J$ は, 実効時定数で減衰するが, 常電導伝搬速度 定まるとする。

上記 $\left(a^{\prime}\right)$ の条件は, 常電導伝搬問題を簡単化する仮 定であり，とりあえず Wilson の伝搬解析結果を援用 することが可能になる(ひがJの減衰により遅くなる ケースについては, 後ほど考察の折に言及する)。

超電導マグネットの等価回路 Fig. 1(b) を用いて, 先 ず自己発熱が無視でき電流減衰が $R_{\mathrm{e}}$ のみによって定 まる (4) 外部保護抵抗型のケースを考える。コイル電 流 $I$ および隇衰時間 $T_{d}=\tau / 2$ は次式でえ与られる。

$$
\begin{aligned}
& I=I_{0} e^{-R_{\mathrm{e}} T / L}=I_{0} e^{-T / \tau}=J_{0} A e^{-T / \tau} \\
& \int_{0}^{\infty} J^{2} d T=J_{0}^{2} \int_{0}^{\infty} e^{-2 T / \tau} d t=J_{0}{ }^{2} \tau / 2 \\
& =J_{0}{ }^{2} T_{\mathrm{d}} \simeq U_{0}\left(\theta_{\mathrm{m}} / \theta_{0}\right)^{1 / 2}(2)
\end{aligned}
$$

$I_{0}[\mathrm{~A}]$ : 初期コイル電流, $A\left[\mathrm{~m}^{2}\right]$ : 導体の断面 積, $\theta_{\mathrm{m}}[\mathrm{K}]:$ 導体の最大温度上昇 つぎに，本題である常電導伝搬による自己発熱と外 部抵抗 $R_{\mathrm{e}}$ 消費の両方を考慮した複合的ケースの基本 式を求める。常電導伝搬に伴う内部抵抗 $R_{\mathrm{i}}$ の増大に より, 電流減衰の実効時定数 $\tau_{\mathrm{eff}}$ は当然外部抵抗のみ 


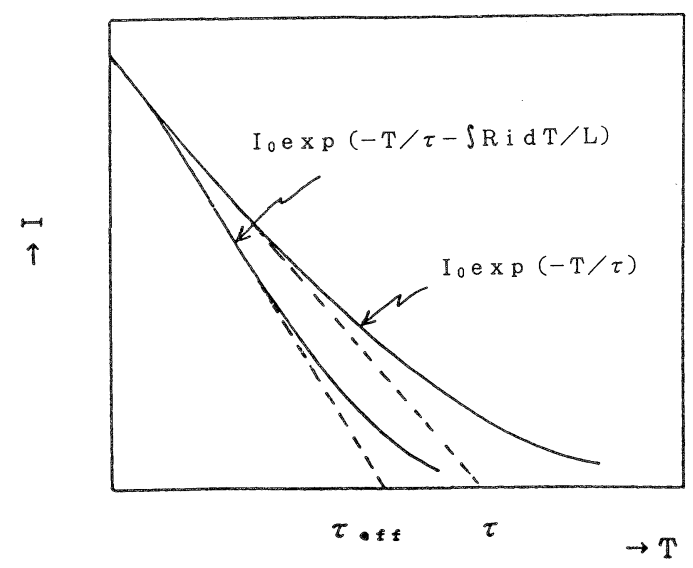

Fig. 2 Decay characteristics of coil current after a quench.

によるてより短かくなる。エネルギー的に, この実効 時定数を含む下記の基本式が成立する（自己発熱と外 部抵抗消費の和が蓄積エネルギーに等しい)。

$$
\begin{aligned}
& I=I_{0} e^{-T / \tau_{\mathrm{eff}}} \\
& L I_{0}^{2} / 2=\int_{0}^{\infty} I^{2} R_{\mathrm{i}} d T+\int_{0}^{\infty} I^{2} R_{\mathrm{e}} d T \\
& \quad=I_{0}^{2} \int_{0}^{\infty} R_{\mathrm{i}} e^{-2 T / \tau_{\mathrm{eff}}} d T+I_{0}^{2} R_{\mathrm{e}} \tau_{\mathrm{eff}} / 2
\end{aligned}
$$

$$
\begin{aligned}
L[\mathrm{H}]: \text { コイルのインダクタンス, } \\
I_{0}[\mathrm{~A}]: \text { 初期コイル電流 }
\end{aligned}
$$

ただし，実際の電流減衰は $e^{-T / \tau_{\mathrm{eff}}}$ ではなく，下 式のようになることに留意する必要がある。

$$
I=I_{0} e^{-\int\left(R_{\mathrm{e}}+R_{\mathrm{i}}\right) d T / L}=I_{0} e^{-\left(\frac{T}{\tau}+\int R_{\mathrm{i}} d T / L\right)}
$$

(1)，（3），（5）の関係を模式的に図示したのが Fig. 2 である。

\section{3. 複合的ヶースの温度上昇近似式}

\section{1 無制限伝搬の場合}

Wilson のホットスポットモデルに基づく常電導部 の伝搬解析結果を援用すると， $R_{\mathrm{i}}$ は次式で与えられ $る^{1)}$ 。

$$
\begin{aligned}
R_{\mathrm{i}} & =\int_{0}^{v T} \frac{4 \pi z^{2} \alpha^{2} \rho_{0} J_{0}^{4}(T-z / v)^{2}}{A^{2} U_{0}^{2}} d z \\
& =\frac{4 \pi \alpha^{2} \rho_{0} J_{0}^{4} \cdot v^{3} T^{5}}{30 A^{2} U_{0}^{2}}=6 F T^{5}
\end{aligned}
$$

$\alpha$ : 非円形度（導体長さ方向 $z$ と垂直方向伝搬 速度 比), $\rho_{0}[\Omega \cdot \mathrm{m}]: \theta_{0}$ における導体の比抵抗
Wilsonの特性時間 $T_{\mathrm{Q}}$ は, マグネットの全エ ネルギーが自己発熱で消費される時間と定義され $\left(\int_{0}^{T_{Q}} I_{0}^{2} R_{\mathrm{i}} d T=L I_{0}^{2} / 2\right)$, 次式で与えられる。

$$
T_{Q}=\left(90 L A^{2} U_{0}^{2} / 4 \pi \alpha^{2} \rho_{0} J_{0}^{4} v^{3}\right)^{1 / 6}=(L / 2 F)^{1 / 6}
$$

ここで, 自己発熱と外部抵抗消費の両方を考慮した 複合的ケースの実効減衰時間 $T_{\mathrm{de}}=\tau_{\mathrm{eff}} / 2$ を求めよう。 （4）式の基本式に式（6)，（7）を代入し時間積分 すると次式が得られる。

$$
\begin{aligned}
& L I_{0}^{2} / 2=6 F I_{0}{ }^{2} \int T^{5} e^{-2 T / \tau_{\mathrm{eff}}} d T+I_{0}^{2} R_{\mathrm{e}} \tau_{\mathrm{eff}} / 2 \\
& =6 ! F I_{0}^{2}\left(\tau_{\mathrm{eff}} / 2\right)^{6} / 2+I_{0}{ }^{2} R_{\mathrm{e}} \tau_{\mathrm{eff}} / 2 \\
& \therefore \quad I=6 ! 2 F\left(\tau_{\text {eff }} / 2\right)^{6} / L+\tau_{\text {eff }} / \tau \\
& =720\left(T_{\mathrm{de}} / T_{\mathrm{Q}}\right)^{6}+2 T_{\mathrm{de}} / \tau \\
& =720 t_{\mathrm{de}}{ }^{6}+t_{\mathrm{de}}\left(2 T_{\mathrm{Q}} / \tau\right) \quad\left(t_{\mathrm{de}}=T_{\mathrm{de}} / T_{\mathrm{Q}}\right)
\end{aligned}
$$

すなわち, 上式の解として実効減衰時間 $T_{\mathrm{de}}$ が得ら れる。この $T_{\mathrm{de}}$ を用いて, 仮定 (b) $J_{0}^{2} T_{\mathrm{de}}=U(\theta)=$ $U_{0}\left(\theta / \theta_{0}\right)^{1 / 2}$ より導体の最大上昇温度 $\theta_{\mathrm{m}}$ は下式のよ うに求められる。

$$
\begin{aligned}
\theta_{\mathrm{m}} & =\theta_{0} J_{0}^{4} T_{\mathrm{de}^{2} / U_{0}{ }^{2}} \\
& =\theta_{0} t_{\mathrm{de}^{2}}\left(90 L A^{2} J_{0}^{8} / 4 \pi \alpha^{2} \rho_{0} v^{3} U_{0}^{4}\right)^{1 / 3}
\end{aligned}
$$

また, 実際の電流減衰波形は（5）式に式(6),

（7）を代入して次式で与えられる。

$$
I=I_{0} e^{-\left(\frac{T}{\tau}+\int R_{\mathrm{i}} d T / L\right)}=I_{0} e^{-\left(\frac{T}{\tau}+\frac{T^{6}}{2 T_{\mathrm{Q}}{ }^{6}}\right)}
$$

\section{2 制限伝搬の場合}

ここでも Wilson と同じモデルを採用し，それに対 応する近似式を求めることとする。

(1) 1 次元制限の場合

常電導部伝搬が 1 次元境界に達する時間を $T_{\mathrm{a}}=$ $a / v$ とすると, 内部抵抗 $R_{\mathrm{i}}$ は次式で与えられる ${ }^{1)} 。$

$$
\begin{aligned}
\int R_{\mathrm{i}} d T= & \frac{4 \pi \alpha^{2} \rho_{0} J_{0} v^{3}}{180 A^{2} U_{0}^{2}}\left\{\int_{0}^{T_{\mathrm{a}}} 6 T^{5} d T\right. \\
& +\int_{T_{\mathrm{a}}}^{T}\left(15 T_{\mathrm{a}} T^{4}-30 T_{\mathrm{a}}{ }^{3} T^{2}\right. \\
& \left.\left.+30 T_{\mathrm{a}}{ }^{4} T-9 T_{\mathrm{a}}{ }^{5}\right) d T\right\}
\end{aligned}
$$

（11）式を基本式（5）に代入し，時間積分を行う と次式が得られ，実効減衰時間 $T_{\mathrm{de}}$ が求められる。

$$
\begin{gathered}
1=\frac{2 F}{L} 6 !\left(\frac{\tau_{\text {eff }}}{2}\right)^{5}\left\{\frac { \tau _ { \text { eff } } } { 2 } \left(1-e^{\left.-2 T_{\mathrm{a}} / \tau_{\text {eff }}\right)}\right.\right. \\
\left.-\frac{T_{\mathrm{a}}}{2} e^{-2 T_{\mathrm{a}} / \tau_{\mathrm{eff}}}\right\}+\frac{2}{\tau}\left(\frac{\tau_{\text {eff }}}{2}\right) \\
\sim 360 T_{\mathrm{a}} T_{\mathrm{de}^{5}} / T_{\mathrm{Q}}{ }^{6}+2 T_{\mathrm{de}} / \tau \\
\left(T_{\mathrm{a}} / 6 T_{\mathrm{de}^{2}} \ll 1\right)
\end{gathered}
$$


ここで, Wilson に倣って規格化 $\left(t_{\mathrm{a}}=T_{\mathrm{a}} / T_{\mathrm{Q}}, t_{\mathrm{de}}=\right.$ $\left.T_{\mathrm{de}} / T_{\mathrm{Q}}\right)$ すると $\left(12^{\prime}\right)$ 式は次式のよう書き直せる。

$$
1=360 t_{\mathrm{a}} t_{\mathrm{de}}{ }^{5}+t_{\mathrm{de}}\left(2 T_{\mathrm{Q}} / \tau\right) \quad\left(t_{\mathrm{a}}{ }^{2} / 6 t_{\mathrm{de}}{ }^{2} \ll 1\right)
$$

実際の電流減衰は，下式で与えられる。

$$
\begin{gathered}
I=I_{0} \exp \left\{-\frac{1}{2}\left(\frac{2 T}{\tau}+\frac{3 t_{\mathrm{a}} T^{5}}{T_{\mathrm{Q}}{ }^{5}}-\frac{10 t_{\mathrm{a}}{ }^{3} T^{3}}{T_{\mathrm{Q}}{ }^{3}}\right.\right. \\
\left.\left.+\frac{15 t_{\mathrm{a}}{ }^{4} T^{2}}{T_{\mathrm{Q}}{ }^{2}}-\frac{9 t_{\mathrm{a}}{ }^{5} T}{T_{\mathrm{Q}}}+2 t_{\mathrm{a}}{ }^{6}\right)\right\} \\
=I_{0} \exp \left\{-\frac{1}{2}\left(\frac{2 T}{\tau}+\frac{3 t_{\mathrm{a}} T^{5}}{T_{\mathrm{Q}}{ }^{5}}\right)\right\} \\
\quad\left(t_{\mathrm{a}} / 6 t_{\mathrm{de}^{2}}{ }^{2} \ll 1\right)
\end{gathered}
$$

(2) 2 次元制限の場合

常電導部伝搬が 2 次元境界に達する時間を $T_{\mathrm{a}}=a / v$ (円筒状) と寸ると内部抵抗 $R_{\mathrm{i}}$ は次式で与えられる1)。

$$
\begin{aligned}
\int R_{\mathrm{i}} d T= & \frac{4 \pi \alpha^{2} \rho_{0} J_{0}^{4} v^{3}}{180 A^{2} U_{0}^{2}}\left\{\int_{0}^{T_{\mathrm{a}}} 6 T^{5} d T\right. \\
& \left.+\int_{T_{\mathrm{a}}}^{T}\left(30 T_{\mathrm{a}}{ }^{2} T^{3}-30 T_{\mathrm{a}}{ }^{3} T^{2}+6 T_{\mathrm{a}}{ }^{5}\right) d T\right\}
\end{aligned}
$$

上式を基本式（5）に代入し時間積分を行らと次式 が得られ，実效減衰時間 $T_{\mathrm{de}}$ が求められる。

$$
\begin{gathered}
1=\frac{2 F}{L}\left[6 ! ( \frac { \tau _ { \text { eff } } } { 2 } ) ^ { 6 } \left(1-e^{\left.-2 T_{\mathrm{a}} / \tau_{\mathrm{aff}}\right)}\right.\right. \\
-6 ! e^{-2 T_{\mathrm{a}} / \tau_{\mathrm{eff}}}\left\{T_{\mathrm{a}}\left(\frac{\tau_{\text {eff }}}{2}\right)^{5}\right. \\
\left.\left.+\frac{T_{\mathrm{a}}{ }^{2}}{4}\left(\frac{\tau_{\text {eff }}}{2}\right)^{4}\right\}\right]+\frac{\tau_{\text {eff }}}{\tau} \\
\sim 180\left(T_{\mathrm{a}}^{2} T_{\mathrm{de}^{4}} / T_{\mathrm{Q}^{\prime}}\right)\left(1-T_{\mathrm{a}} / 3 T_{\mathrm{de}}\right)+2 T_{\mathrm{de}} / \tau \\
\left(3 T_{\mathrm{a}} / 8 T_{\mathrm{de}}{ }^{2} \ll 1\right) \quad\left(16^{\prime}\right) \\
\sim 180 t_{\mathrm{a}}{ }^{2} t_{\mathrm{de}}{ }^{4}\left(1-t_{\mathrm{a}} / 3 t_{\mathrm{de}}\right)+t_{\mathrm{de}}\left(2 T_{\mathrm{Q}} / \tau\right) \\
\left(3 t_{\mathrm{a}} / 8 t_{\mathrm{de}}{ }^{2} \ll 1\right) \quad\left(16^{\prime \prime}\right)
\end{gathered}
$$

棈円筒状制限の場合には, $T_{\mathrm{a}}=a / v, T_{\mathrm{b}}=b / \alpha v, t_{\mathrm{a}}=$ $T_{\mathrm{a}} / T_{\mathrm{Q}}, t_{\mathrm{b}}=T_{\mathrm{b}} / T_{\mathrm{Q}}$ として, $t_{\mathrm{de}}=T_{\mathrm{de}} / T_{\mathrm{Q}}$ は下式から求 まる。

$$
\begin{array}{r}
1=\frac{6 ! t_{\mathrm{a}} t_{\mathrm{b}} t_{\mathrm{de}} \mathrm{e}^{4}}{4}\left(1-\frac{\sqrt{t_{\mathrm{a}} t_{\mathrm{b}}}}{3 t_{\mathrm{de}}}\right)+\frac{2 t_{\mathrm{de}} T_{\mathrm{Q}}}{\tau} \\
\left(3 t_{\mathrm{a}} t_{\mathrm{b}} / 8 t_{\mathrm{de}^{2}} \ll 1\right)
\end{array}
$$

（3） 3 次元制限の場合

常電導部伝搬が 3 次元境界に達する時間を $T_{\mathrm{a}}$ とす ると, 内部抵抗 $R_{\mathrm{i}}$ は次式で与えられる ${ }^{1)}$

$$
\begin{aligned}
\int R_{\mathrm{i}} d T= & \frac{4 \pi \alpha^{2} \rho_{0} J_{0}{ }^{4} \vartheta^{3}}{180 A^{2} U_{0}{ }^{2}}\left\{\int_{0}^{T_{\mathrm{a}}} 6 T^{5} d T\right. \\
& \left.+\int_{T_{\mathrm{a}}}^{T}\left(60 T_{\mathrm{a}}{ }^{3} T^{2}-90 T_{\mathrm{a}^{4}} T+36 T_{\mathrm{a}}{ }^{5}\right) d T\right\}
\end{aligned}
$$

上式を基本式 (5) に代入し, 時間積分すると次式 が得られ, 実効減衰時間 $T_{\mathrm{de}}$ が求まる。

Vol. 28 No. 8 (1993)

Table 1 Ratings of small-scaled magnet for SMES.

Type of magnet

Number of coils

Number of turns

Stored energy

Initial energy

Maximum field strength

Major radius

Minor radius

Coil height

Coil thickness

Conductor length

Weight of conductor

Change in field

Change in current

Withstand voltage

Toroidal
12
2,160
$480 \mathrm{MJ}$
$300 \mathrm{MJ}$
$4.7 \mathrm{~T}(4.2 \mathrm{~K})$
$5.7 \mathrm{~m}$
$1.7 \mathrm{~m}$
$0.532 \mathrm{~m}$ (Fig. 3 ref.)
$0.217 \mathrm{~m}$ (Fig. $3 \mathrm{ref}$.
$23.2 \mathrm{~km}$
$48.8 \times 10^{3} \mathrm{~kg}$
$3.56 \mathrm{~T} \longleftrightarrow 2.25 \mathrm{~T}$
$15.8 \mathrm{kA} \longleftrightarrow 10 \mathrm{kA}$
$3 \mathrm{kV}$

$$
\begin{aligned}
1= & \frac{2 F}{L}\left\{6 ! ( \frac { \tau _ { \text { eff } } } { 2 } ) ^ { 6 } \left(1-e^{\left.-2 T_{\mathrm{a}} / \tau_{\text {eff }}\right)}\right.\right. \\
& \left.-6 !\left(\frac{\tau_{\text {eff }}}{2}\right)^{4} e-2 T_{\mathrm{a}} / \tau_{\text {eff }}\left(\frac{T_{\mathrm{a}}}{2}+\frac{\tau_{\text {eff }}}{2}\right) T_{\mathrm{a}}\right\} \\
& +\tau_{\text {eff }} / \tau
\end{aligned}
$$

$$
\begin{gathered}
\sim 120\left(T_{\mathrm{a}}{ }^{3} T_{\mathrm{de}^{3} /} / T_{\mathrm{Q}}{ }^{6}\right)\left(1-3 T_{\mathrm{a}} / 4 T_{\mathrm{de}}\right)+2 T_{\mathrm{de}} / \tau \\
\left(T_{\mathrm{a}}{ }^{2} / 4 T_{\mathrm{de}^{2}} \ll 1\right) \quad\left(19^{\prime}\right) \\
\sim 120 t_{\mathrm{a}}{ }^{3} t_{\mathrm{de}}{ }^{3}\left(1-3 t_{\mathrm{a}} / 4 t_{\mathrm{de}}\right)+t_{\mathrm{de}}\left(2 T_{\mathrm{Q}} / \tau\right)
\end{gathered}
$$$$
\left(t_{\mathrm{a}}{ }^{2} / 4 t_{\mathrm{de}}{ }^{2} \ll 1\right)
$$

ここで, 3 次元境界に達する時間がそれぞれ $T_{\mathrm{a}}=a / v$, $T_{\mathrm{b}}=b / \alpha v, T_{\mathrm{c}}=c / \alpha v, t_{\mathrm{a}}=T_{\mathrm{a}} / T_{\mathrm{Q}}, t_{\mathrm{b}}=T_{\mathrm{b}} / T_{\mathrm{Q}}, t_{\mathrm{c}}=T_{\mathrm{c}} /$ $T_{\mathrm{Q}}$ の場合には, $t_{\mathrm{de}}=T_{\mathrm{de}} / T_{\mathrm{Q}}$ は次式少的求另れる。

$$
\begin{array}{r}
1=120 t_{\mathrm{a}} t_{\mathrm{b}} t_{\mathrm{c}} t_{\mathrm{de}}{ }^{3}\left(1-3 \sqrt[3]{t_{\mathrm{a}} t_{\mathrm{b}} t_{\mathrm{c}}} / 4 t_{\mathrm{de}}\right)+t_{\mathrm{de}}\left(2 T_{\mathrm{Q}} / \tau\right) \\
\left(\left(t_{\mathrm{a}} t_{\mathrm{b}} t_{\mathrm{c}}\right)^{2 / 3} / 4 t_{\mathrm{de}}{ }^{2} \ll 1\right) \quad(20)
\end{array}
$$

以上導出した本近似式とコイル自己発熱のみを考虑 した Wilsonの近似式を対照して付録に掲げる。

\section{SMES 用導体の温度上昇解析}

\section{1 コイル構成と特性値の修正}

本解析法の適用対象として, 小規模超電導エネルギ 一蓄積 (SMES) 用コイルを取り上げることとする。 本 SMES コイル系は Table 12) のごとく12 コイル よりなる浸漬冷却型トロイドであり，1コイル当りの 蓄積エネルギーは $40 \mathrm{MJ}$ である。各コイルは導体を パンターキ巻きし (15 層), このパンケーキをスペー サを介して 12 段積み重祖構成される。Fig. 3 に示さ れる本コイル構成において, 常電導部の発生点をコイ 


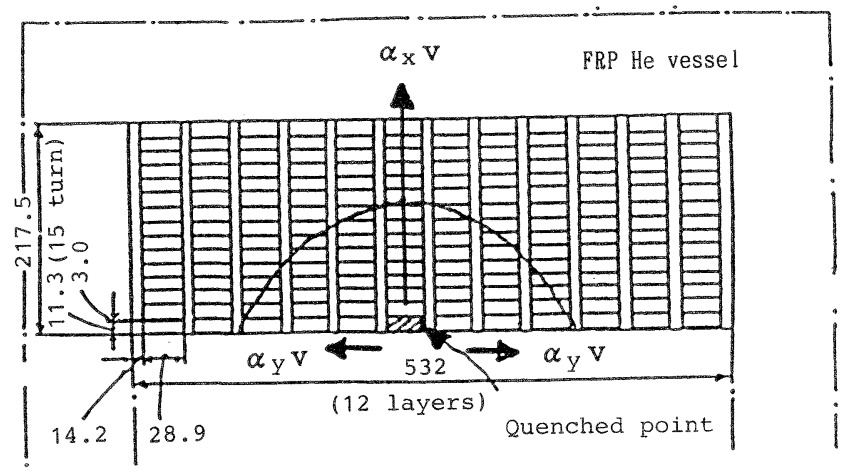

Fig. 3 Propagation of normal zone in the coil.

Table 2 Designs in pool-boiled $\mathrm{Nb}-\mathrm{Ti}$ Cable conductor.

\begin{tabular}{ll}
\hline Critical current & $40 \mathrm{kA}$ \\
Current density & $2,250 \mathrm{~A} / \mathrm{mm}^{2}$ \\
Filament dia. & $4.5 \mu \mathrm{m}$ \\
Spacing between fil. & $1.6 \mu \mathrm{m}$ \\
Number of fil. per strand & 4,444 \\
Strand diameter & $0.6 \mathrm{~mm}$ \\
Ratio Cu/CuNi/NbTi & $2: 1: 1$ \\
Twist pitch & $7.5 \mathrm{~mm}$ \\
Ratio CuNi/Cu in stabilizer & $1: 6.7$ \\
Stranding pitch & $40 \mathrm{~mm}, 250 \mathrm{~mm}^{-1}$ \\
Dimension of reinforcement & $3.5 \times 21.1 \mathrm{~mm}^{2}$ \\
Dimension of superconductor & $11.3 \times 28.9 \mathrm{~mm}^{2}$ \\
Coil current density & $32.8 \mathrm{~A} / \mathrm{mm}^{2}$ \\
\hline
\end{tabular}

ル最内層の中央部とし，この常電導域の伝搬は導体の 長さ方向 $(z)$ にはvの速度, コイル径方向 $(x)$ お よび軸方向（y）にはそれぞれ $\alpha_{x} v$ および $\alpha_{y} v$ の速 度で進行すると仮定する。このような仮定の下では, Wilsonの特性式を下記のように修正する必要がある。

$$
\begin{aligned}
& F^{\prime}=\pi \alpha_{1} \alpha_{2} \rho_{0} J_{0}^{4} v^{3} / 180 A^{2} U_{0}^{2} \\
& T_{Q^{\prime}}=\left(90 L A^{2} U_{0}^{2} / \pi \alpha_{1} \alpha_{2} \rho_{0} J_{0}^{4} v^{3}\right)^{1 / 6} \\
& \alpha_{x, y}=\left\{(\gamma C)_{\text {metal }} /(\gamma C)_{a v}\right\}\left(\kappa_{x, y} / \kappa_{z}\right)^{1 / 2}
\end{aligned}
$$

$\kappa_{z}, \kappa_{x}, \kappa_{y}[\mathrm{~W} / \mathrm{m} \cdot \mathrm{K}]:$ コイル周方向, 径方向および軸 方向の熱伝導率

\section{2 本劕体の伝搬速度 $v$}

本コイルに用いられる導体は，3 層構造素線による 2 重撚線成形ケーブル導体 (CuNi 条補強) であり, 低交流損失 $(13.7 \mathrm{~mW} / \mathrm{m}$ at $0.146 \mathrm{~T} / \mathrm{s})$ かつ高安定 ( $\alpha=1.1)$ が特徴であり, 導体諸元と断面図を Table 2 および Fig. 4 に示す ${ }^{2)}$ 。図示のように，1次撚線は半

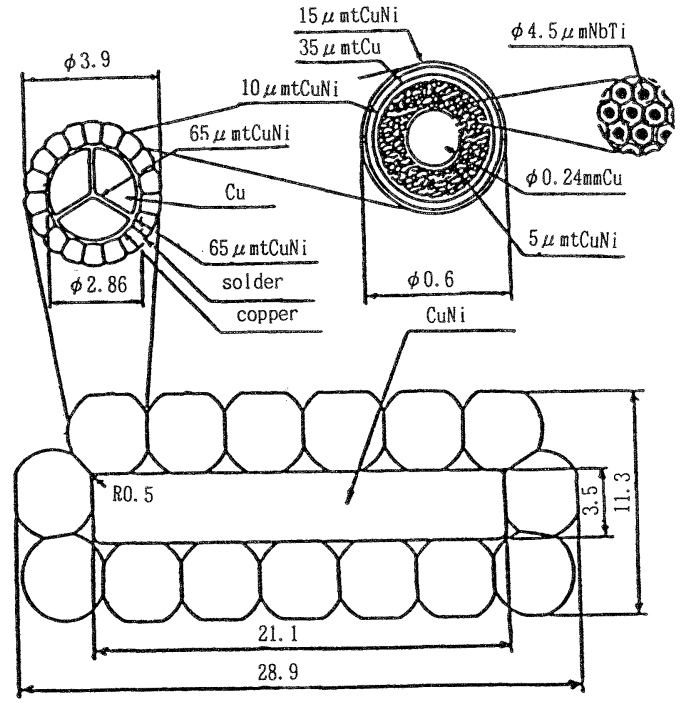

Fig. 4 Schematic view of Nb-Ti alloy cable conductor designed.

田含浸により電気的, 熱的に一体に結合されている が，2次撚線ケーブル内は単に機械的に接触した状態 にある。したがって，常電導伝搬速度vの計算には $\mathrm{CuNi}$ 補強材の寄与は無視し，2次撚線部のみを考慮 して下式を用いる ${ }^{1,3)}$ 。

$$
\begin{aligned}
& v=v_{\mathrm{ad}}(1-2 Y) /\left(Y Z^{2}+Z+1-Y\right)^{1 / 2} \\
& v_{\mathrm{ad}}=J_{0 \mathrm{c}}\left\{L_{0} \theta_{\mathrm{s}} /\left(\theta_{\mathrm{s}}-\theta_{\mathrm{b}}\right)\right\}^{1 / 2} /(\gamma C) \text { eond } \\
& (\gamma C)_{\text {eond }}=\left\{\left(\theta_{\mathrm{c}}^{4}-\theta_{\mathrm{b}}{ }^{4}\right) / 4 \theta_{\mathrm{b}}{ }^{3}\left(\theta_{\mathrm{c}}-\theta_{\mathrm{b}}\right)\right\} \Sigma \gamma_{\mathrm{i}} c_{\mathrm{i}} \lambda_{\mathrm{i}}
\end{aligned}
$$

$$
Y=\left(\theta_{\mathrm{s}}-\theta_{\mathrm{b}}\right) /\left(\theta_{1}-\theta_{\mathrm{b}}\right)=h \rho\left(\theta_{\mathrm{s}}-\theta_{\mathrm{b}}\right) / A J^{2} \rho
$$

$$
Z=Q_{\mathrm{L}} / \gamma C\left(\theta_{\mathrm{s}}-\theta_{\mathrm{b}}\right)
$$

ただし， $L_{0}=2.45 \times 10^{-8} \mathrm{~W} \Omega / \mathrm{K}^{2}, \theta_{\mathrm{s}}=\left(\theta_{\mathrm{g}}+\theta_{\mathrm{c}}\right) / 2$

$\theta_{\mathrm{c}}$ : 臨界温度, $\theta_{\mathrm{b}}$ : 冷媒温度, $\theta_{\mathrm{s}}$ : 転移開 
Table 3 Properties used for calculations.

\begin{tabular}{cccccc}
\hline & $\begin{array}{c}\text { Density } \\
{\left[\mathrm{kg} / \mathrm{m}^{3}\right]}\end{array}$ & $\begin{array}{c}\text { Specific } \\
\text { heat } \\
{[\mathrm{J} / \mathrm{kg} / \mathrm{K}]}\end{array}$ & $\begin{array}{c}\text { Cross-sectional } \\
\text { area } \\
{\left[\mathrm{m}^{3}\right]}\end{array}$ & Packing factor & $\begin{array}{c}\text { Heat } \\
\text { capacity } \\
{\left[\mathrm{J} / \mathrm{m}^{3} / \mathrm{K}\right]}\end{array}$ \\
\hline Cu & 8,960 & 0.11 & $1.22 \mathrm{E}-04$ & $3.73 \mathrm{E}-01$ & $3.68 \mathrm{E}+02$ \\
$9 / 1 \mathrm{CuNi}$ (reinforcement) & 8,960 & 0.11 & $7.93 \mathrm{E}-05$ & $2.26 \mathrm{E}-01$ & $2.23 \mathrm{E}+02$ \\
$9 / 1 \mathrm{CuNi(SC)}$ & 8,960 & 0.11 & $3.17 \mathrm{E}-05$ & $9.69 \mathrm{E}-02$ & $9.55 \mathrm{E}+01$ \\
$\mathrm{NbTi}$ & 6,100 & 0.74 & $1.91 \mathrm{E}-05$ & $5.84 \mathrm{E}-02$ & $2.64 \mathrm{E}+02$ \\
$\mathrm{PbSn}$ & 8,860 & 0.5 & $1.00 \mathrm{E}-05$ & $3.06 \mathrm{E}-02$ & $1.35 \mathrm{E}+02$ \\
sum & & $2.57 \mathrm{E}-04$ & $7.58 \mathrm{E}-01$ & $1.09 \mathrm{E}+03$ \\
\hline
\end{tabular}

Table 4 Function $U(\theta)$ in copper dependent on temperature $\theta$.

\begin{tabular}{|c|c|c|c|c|c|}
\hline$\theta$ & $U(\theta)$ & $\theta$ & $U(\theta)$ & $\theta$ & $U(\theta)$ \\
\hline (K) & $(A-2 \mathrm{sec} / \mathrm{m} 4)$ & (K) & $(\mathrm{A}-2 \mathrm{sec} / \mathrm{m} 4)$ & $(\mathrm{K})$ & $(A-2 \mathrm{sec} / \mathrm{m} 4)$ \\
\hline 4.2 & & 85 & $8.964 E+16$ & 900 & $2.324 \mathrm{E}+17$ \\
\hline 4.5 & 2. $349 \mathrm{E}+12$ & 90 & $9.347 \mathrm{E}+16$ & 925 & 2. $341 \mathrm{E}+17$ \\
\hline 5 & $7.055 \mathrm{E}+12$ & 95 & 9. $697 \mathrm{E}+16$ & 950 & 2. $357 \mathrm{E}+17$ \\
\hline 5.5 & 1. $280 \mathrm{E}+13$ & 100 & 1. $002 \mathrm{E}+17$ & 975 & $2.373 \mathrm{E}+17$ \\
\hline 6 & 1. $931 \mathrm{E}+13$ & 110 & $1.061 \mathrm{E}+17$ & 1,000 & 2. $388 \mathrm{E}+17$ \\
\hline 6.5 & $2.739 \mathrm{E}+13$ & 120 & 1. $115 \mathrm{E}+17$ & 1,025 & $2.403 E+17$ \\
\hline 7 & $3.759 \mathrm{E}+13$ & 130 & 1. $164 \mathrm{E}+17$ & 1,050 & $2.418 \mathrm{E}+17$ \\
\hline 7.5 & 4. $967 E+13$ & 140 & 1. $207 \mathrm{E}+17$ & 1,075 & 2. $432 \mathrm{E}+17$ \\
\hline 8 & $6.385 \mathrm{E}+13$ & 150 & 1. $247 \mathrm{E}+17$ & 1,100 & 2. $446 \mathrm{E}+17$ \\
\hline 8.5 & $8.045 E+13$ & 160 & 1. $285 \mathrm{E}+17$ & 1,125 & $2.460 \mathrm{E}+17$ \\
\hline 9 & 1. $004 \mathrm{E}+14$ & 170 & 1. $320 \mathrm{E}+17$ & 1,150 & $2.473 \mathrm{E}+17$ \\
\hline 9.5 & 1. $237 \mathrm{E}+14$ & 180 & 1. $354 \mathrm{E}+17$ & 1,175 & 2. $486 \mathrm{E}+17$ \\
\hline 10 & $1.501 E+14$ & 190 & 1. $385 \mathrm{E}+17$ & $1,2,00$ & 2. $499 \mathrm{E}+17$ \\
\hline 11 & 2. $117 \mathrm{E}+14$ & 200 & 1. $415 \mathrm{E}+17$ & 1,225 & $2.511 \mathrm{E}+17$ \\
\hline 12 & $2.868 \mathrm{E}+14$ & 225 & 1. $483 \mathrm{E}+17$ & 1,250 & $2.523 \mathrm{E}+17$ \\
\hline 13 & $3.829 \mathrm{E}+14$ & 250 & $1.544 \mathrm{E}+17$ & 1,275 & $2.535 \mathrm{E}+17$ \\
\hline 14 & $5.022 \mathrm{E}+14$ & 275 & 1. $601 \mathrm{E}+17$ & 1,300 & $2.547 \mathrm{E}+17$ \\
\hline 15 & $6.556 \mathrm{E}+14$ & 300 & 1. $654 \mathrm{E}+17$ & 1,325 & $2.558 \mathrm{E}+17$ \\
\hline 16 & $8.507 \mathrm{E}+14$ & 325 & 1. $703 \mathrm{E}+17$ & 1,350 & $2.570 \mathrm{E}+17$ \\
\hline 17 & $1.086 \mathrm{E}+15$ & 350 & 1. $748 \mathrm{E}+17$ & 1,375 & $2.581 \mathrm{E}+17$ \\
\hline 18 & 1. $378 \mathrm{E}+15$ & 375 & 1. $791 \mathrm{E}+17$ & 1,400 & $2.592 \mathrm{E}+17$ \\
\hline 19 & 1. $739 \mathrm{E}+15$ & 400 & 1. $830 \mathrm{E}+17$ & 1,425 & 2. $602 \mathrm{E}+17$ \\
\hline 20 & $2.162 \mathrm{E}+15$ & 425 & $1.867 \mathrm{E}+17$ & 1,450 & 2. $613 \mathrm{E}+17$ \\
\hline 22.5 & $3.439 E+15$ & 450 & $1.902 \mathrm{E}+17$ & 1,475 & $2.623 \mathrm{E}+17$ \\
\hline 25 & 5. $314 \mathrm{E}+15$ & 475 & 1. $936 \mathrm{E}+17$ & 1,500 & 2. $633 \mathrm{E}+17$ \\
\hline 27.5 & $8.064 E+15$ & 500 & 1. $967 \mathrm{E}+17$ & 1,525 & 2. $643 \mathrm{E}+17$ \\
\hline 30 & 1. $156 \mathrm{E}+16$ & 525 & 1. $997 \mathrm{E}+17$ & 1,550 & 2. $653 \mathrm{E}+17$ \\
\hline 32.5 & $1.594 \mathrm{E}+16$ & 550 & $2.025 \mathrm{E}+17$ & 1,575 & 2. $663 \mathrm{E}+17$ \\
\hline 35 & $2.108 E+16$ & 575 & 2. $052 \mathrm{E}+17$ & 1,600 & 2. $672 \mathrm{E}+17$ \\
\hline 37.5 & 2. $651 \mathrm{E}+16$ & 600 & $2.078 \mathrm{E}+17$ & 1,625 & 2. $682 \mathrm{E}+17$ \\
\hline 40 & $3.199 E+16$ & 625 & 2. $103 \mathrm{E}+17$ & 1,650 & $2.691 \mathrm{E}+17$ \\
\hline 42.5 & $3.732 \mathrm{E}+16$ & 650 & 2. $127 \mathrm{E}+17$ & 1,675 & $2.700 \mathrm{E}+17$ \\
\hline $\begin{array}{r}45 \\
47.5\end{array}$ & $\begin{array}{l}\text { 4. } 229 \mathrm{E}+16 \\
4.678 \mathrm{E}+16\end{array}$ & $\begin{array}{l}675 \\
700\end{array}$ & $\begin{array}{l}2.150 \mathrm{E}+17 \\
2.172 \mathrm{E}+17\end{array}$ & $\begin{array}{l}1,700 \\
1,725\end{array}$ & $\begin{array}{l}2.709 \mathrm{E}+17 \\
2.718 \mathrm{E}+17\end{array}$ \\
\hline 50 & 5. $106 \mathrm{E}+16$ & 725 & 2. $193 \mathrm{E}+17$ & 1,750 & $2.726 \mathrm{E}+17$ \\
\hline 55 & $5.893 \mathrm{E}+16$ & 750 & $2.214 \mathrm{E}+17$ & 1,775 & $2.735 \mathrm{E}+17$ \\
\hline 60 & $6.549 E+16$ & 775 & 2. $234 \mathrm{E}+17$ & 1,800 & $2,743 \mathrm{E}+17$ \\
\hline 65 & $7.120 \mathrm{E}+16$ & 800 & 2. $253 \mathrm{E}+17$ & 1,825 & 2. $752 \mathrm{E}+17$ \\
\hline 70 & $7.651 \mathrm{E}+16$ & 825 & $2.272 \mathrm{E}+17$ & 1,850 & $2,760 \mathrm{E}+17$ \\
\hline 75 & $8.136 \mathrm{E}+16$ & 850 & 2. $290 \mathrm{E}+17$ & 1,875 & 2. $768 \mathrm{E}+17$ \\
\hline 80 & $8.564 \mathrm{E}+16$ & 875 & 2. $307 \mathrm{E}+17$ & 1,900 & $2.776 \mathrm{E}+17$ \\
\hline
\end{tabular}




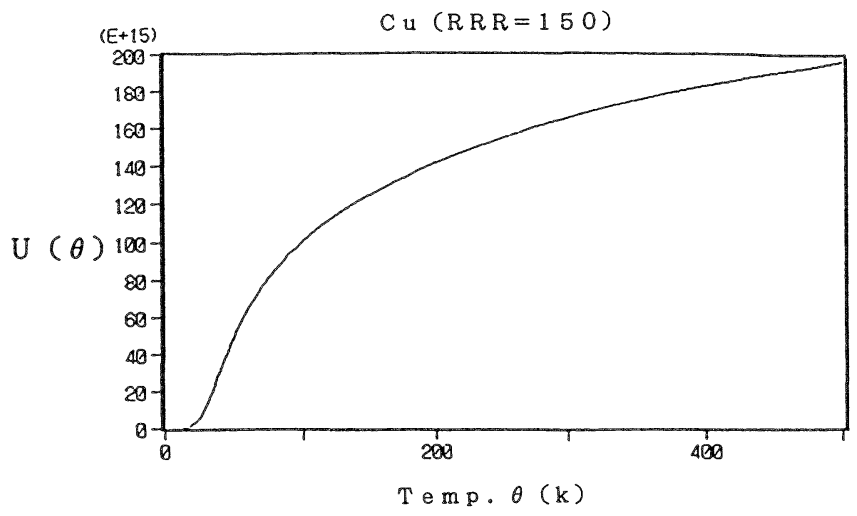

Fig. 5 Temperature dependence of function $U(\theta)$ in copper.

始温度, $\theta_{\mathrm{g}}$ : 分流開始温度, $\theta_{1}$ : 常電導部 定常温度, $\theta_{\mathrm{L}}$ : 単位体積当りの潜熱

Table 3 の物性値と上式を用いて $v_{x}, v_{y}$ を計算す ると, 次の值が得られる $(Y \sim 0.2, Z \sim 10)$ 。

$$
\left\{\begin{array}{r}
v=v_{\mathrm{ad}}(1-2 Y) /\left(Y Z^{2}+Z+1-Y\right)^{1 / 2} \\
=1.75 \times 0.6 / 5.57=1.9[\mathrm{~m} / \mathrm{s}] \\
v_{x}=\alpha_{x} v=6.2 \times 10^{-3} \times 1.9 \sim 1.2 \times 10^{-2} \\
{[\mathrm{~m} / \mathrm{s}]} \\
v_{y}=\alpha_{y} v=1.6 \times 10^{-3} \times 1.9 \sim 3.0 \times 10^{-3} \\
{[\mathrm{~m} / \mathrm{s}]}
\end{array}\right.
$$

\section{3 導体温度上昇の近似計算}

まず銅のみの $U_{\mathrm{Cu}}(\theta)=\int_{4.2}^{\theta}(\gamma C / \rho) \mathrm{Cu} d \theta$ を $\mathrm{Cu}$ のデ 一夕を用いて Table 4 のように計算して押く。次に 常電導伝搬に必要なコイル平均の物性値を求めるため に下記の平均化式を適用すると Table 5 の諸元が得 られる。

$$
\left\{\begin{aligned}
(\gamma C)_{\mathrm{av}}= & (\gamma C)_{\mathrm{Cu}} \lambda_{\mathrm{con}}\left(\lambda_{\mathrm{Cu}}+\lambda_{\mathrm{CuNi}}\right. \\
& \left.+\lambda_{\mathrm{NbTi}}\right) \\
(\rho)_{\mathrm{av}}= & \rho_{\mathrm{Cu}} / \lambda_{\mathrm{Cu}} \lambda_{\mathrm{con}} \\
U_{\mathrm{av}}(\theta)= & \lambda_{\mathrm{Cu}} \lambda_{\mathrm{con}}{ }^{2}\left(\lambda_{\mathrm{Cu}}+\lambda_{\mathrm{CuNi}}\right. \\
& \left.+\lambda_{\mathrm{NbTi}}\right) U_{\mathrm{Cu}}(\theta)
\end{aligned}\right.
$$

ただし, $\lambda_{\mathrm{con}}=A_{\mathrm{con}} / A$ : コイル断面中の導体充填率, $\lambda_{\mathrm{Cu}}=A_{\mathrm{Cu}} / A_{\mathrm{con}}, \quad \lambda_{\mathrm{CuNi}}=A_{\mathrm{CuNi}} / A_{\mathrm{con}}, \lambda_{\mathrm{NbTi}}=A_{\mathrm{NbTi}} /$ $A_{\text {con }}$ : 導体断面中のそれぞれ $\mathrm{Cu}, \mathrm{CuNi}$ および $\mathrm{NbTi}$ の充填率。

以上の準備の下先ず $\theta_{0}=100 \mathrm{~K}$ で $U_{0}=6.16 \times$ $10^{15} \mathrm{~A}^{2} \mathrm{~s} / \mathrm{m}^{4}$ の值を（22）式に代入して $T_{\mathrm{Q}^{\prime}}$ を求め, $T_{\mathrm{a}}=5.3 / 1.9=2.81$ および $\tau=16.5 \mathrm{~s}$ と $\left(12^{\prime}\right)$ 式を用 いて $T_{\mathrm{de}}$ を求め, 最後に $(9)$ 式により $\theta_{\mathrm{m}}$ を計算 する。得られた $\theta_{\mathrm{m}}$ が最初の $\theta_{0}$ と異なれば, 得られ

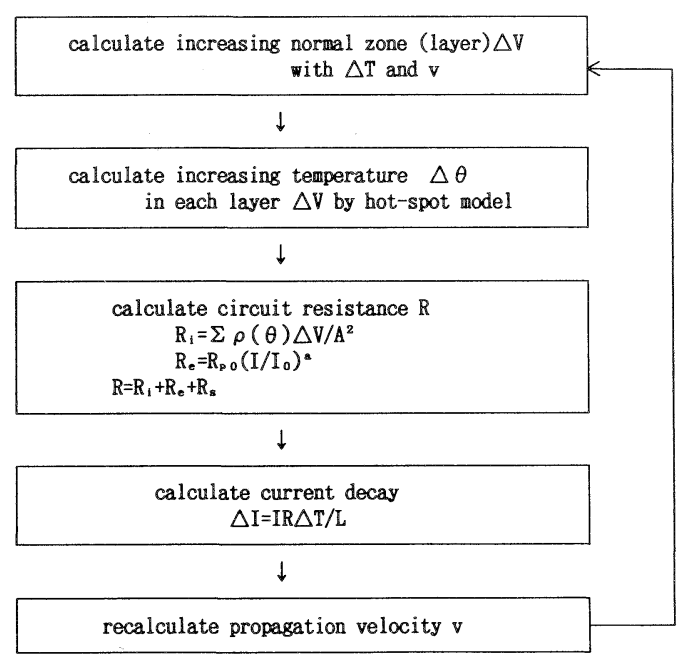

Fig. 6 Flow chart of computer simulations.

た温度の $U_{0}$ を入れ直して再計算するプロセスを数回 繰り返すと次のような収斂值が得られる (Table 5)。

$$
\left\{\begin{aligned}
1= & 360 T_{\mathrm{a}} T_{\mathrm{de}^{5}} / T_{\mathrm{Q}^{6}}+2 T_{\mathrm{de}} / \tau \\
= & 360 \times 2.81 \times 6.7^{5} / 20.7^{6} \\
& +2 \times 6.7 / 16.5 \\
\theta_{\mathrm{m}}= & \theta_{0} J_{0}{ }^{4} T_{\mathrm{de}^{2}} / U_{0}{ }^{2}=125 \times 3.24^{4} \times 10^{28} \\
& \times 6.7^{2} / 7.02^{2} \times 10^{30}=124.9[\mathrm{~K}]
\end{aligned}\right.
$$

\section{5. 計算機によるクエンチシミュレーション}

前節の近似計算結果を検証するため，Wilson が開 発したプログラム“QUENCH”を用いで), 前記の SMES マグネットの計算機シミュレーションを行っ たので，その結果について述べる。

本プログラムのフローチャートを Fig. 6 に示す。コ 低 温工 学 


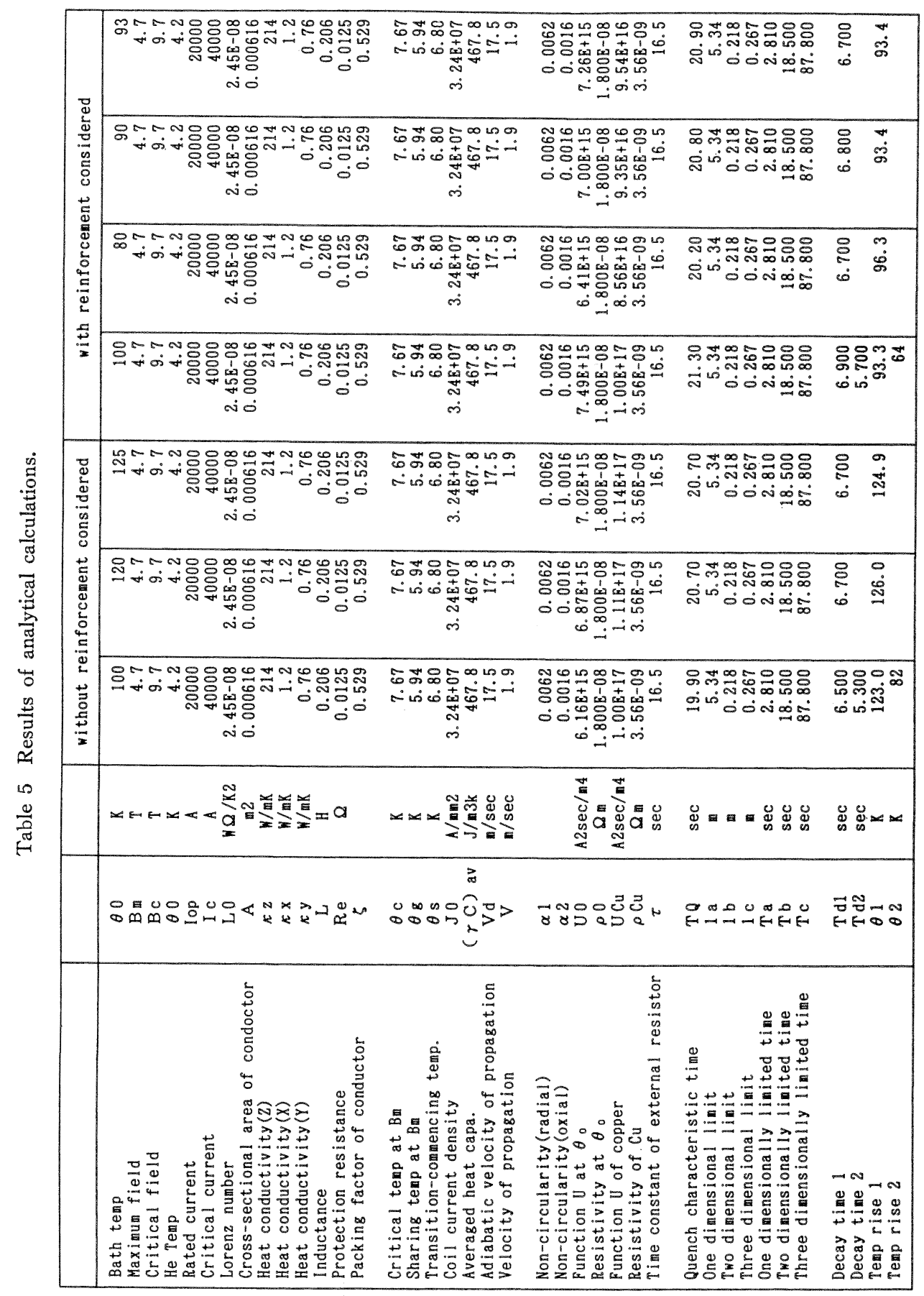




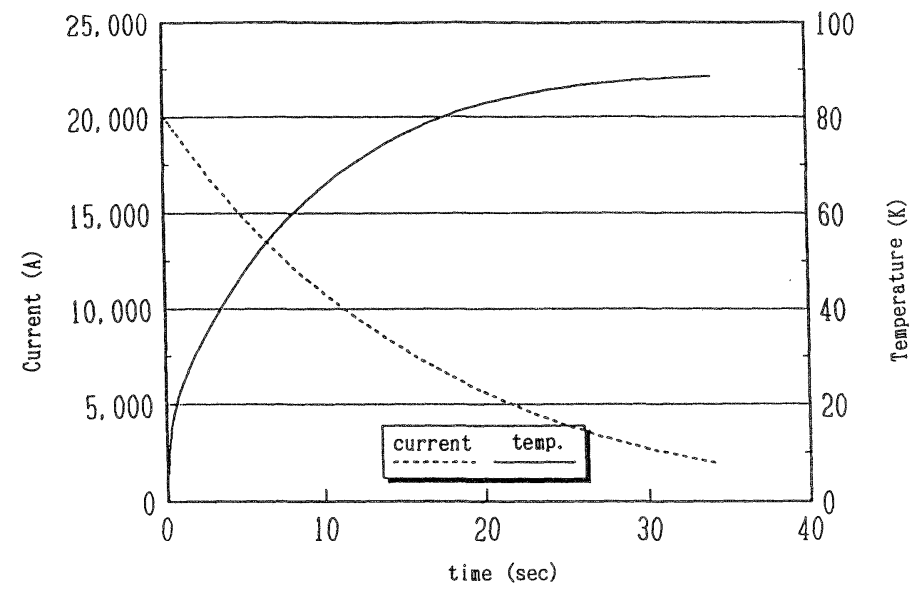

Fig. 7 Results of computer simulation (a): temperature vs. time $\&$ current vs. time.

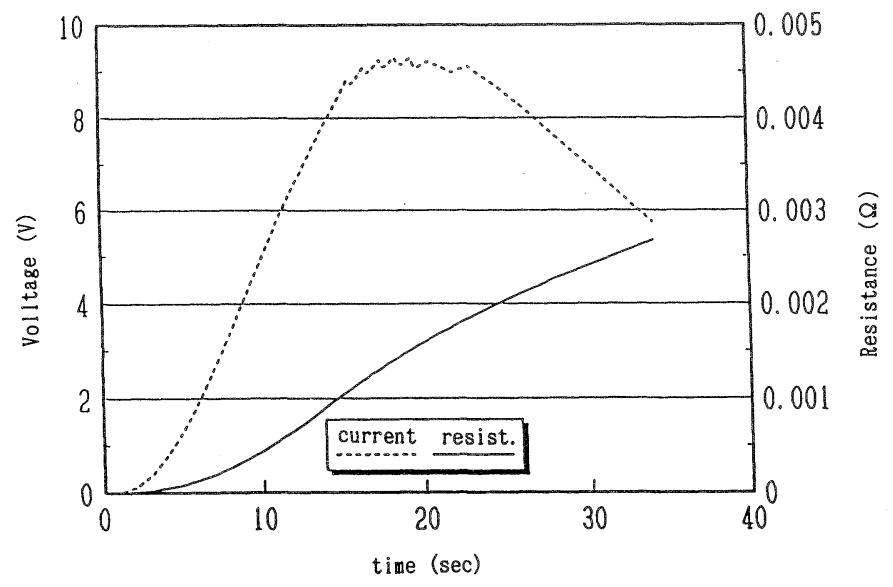

Fig. 8 Results of computer simulation (b): resistance vs. time $\&$ voltage vs. time.

イルの諸元および各パラメータの初期值として線材断 面積 $A$, 構成材物性値 $(\gamma C, \rho)$, 通電電流 $I_{0}$, インダ クタンス $L$, 保護抵抗 $R_{\mathrm{e}}$ ，スイッチ抵抗 $R_{\mathrm{s}}$, コイル の直方体展開時の大きさ, クエンチ開始位置を与え る。初期常電導域伝搬速度 vo については数值として 与える場合とプログラム中で計算により求める場合が ある。ここでは, $v_{0}=1.9 \mathrm{~m} / \mathrm{s}$ を与えた。

計算手順としては, まず時間増分 $\Delta T$ に従ってvか ら常電導領域の増分 $\Delta V$ を求める。したがって常電導 域は $\Delta T$ ごとの $\Delta V$ が積層しながら増加していく。 各 $\Delta V$ 領域内の温度上昇 $\Delta \theta$ はホットスポットモデル から計算する。 $\Delta \theta$ から各 $\Delta V$ の温度 $\theta$ を求め, コイ
ルの抵抗を算出する。回路の合成抵抗から電流減衰量 を計算し, vを求め（ただしここでは $v=v_{0}$ 固定とし た）再び $\Delta T$ 後の新たな $\Delta V$ を計算する。

この逐次計算によって得られた補強材を考慮しない 場合のシミュレーション結果を Fig. 7 と Fig. 8 に示 す。Fig. 7 からクエンチ後 $I$ が $I_{0}$ の $1 / 10$ となる $34 \mathrm{~s}$ 後の $\theta_{\mathrm{m}}$ は $88.6 \mathrm{~K}$ で, 前節の解析的に求めた值 $\theta_{\mathrm{m}}$ $=124.9 \mathrm{~K}$ より $36 \mathrm{~K}$ ほど低い值である。また, 電流 $I$ が $I_{0}$ の $1 / e$ に降下する時間 $\tau_{\mathrm{eff} f^{\prime}}$ (Fig. 2 の $\tau_{\mathrm{eff}}$ に対応する）を求めると $\tau_{\mathrm{eff}}{ }^{\prime}=16 \mathrm{~s}$ であり，解析的 に求めた $\tau_{\mathrm{eff}}=2 T_{\mathrm{de}}=13.4 \mathrm{~s}$ 上り若干長い。Fig. 8 加 らは，コイル内部電圧がクエンチ後 $18.5 \mathrm{~s}$ で最大值 低 温工学 
$9.3 \mathrm{~V}$ に達し, その後漸時減少することがわかる。

一方, 図示はしていないが $\mathrm{CuNi}$ 補強材の熱容量 （50\%) を考慮した場合 (Table 5 右欄に対応）のシ ミュレーションも行っており, クエンチ後 $34 \mathrm{~s} て ゙ ~ \theta_{\mathrm{m}}$ $=78.7 \mathrm{~K}$ に温度上昇し, $\tau_{\mathrm{eff}}{ }^{\prime}=16 \mathrm{~s}$ の結果を得てい る。解析的に求めた值 $\theta_{\mathrm{m}}=93.4 \mathrm{~K}$ に比して CuNi, 補強材を考慮しない場合と同様に低めの值になってい る。

\section{6. 考察}

\section{1 シミュレーションとの比較}

前節で述べたシミュレーション結果によれば，本近 似式による計算值はシミュレーション值に比して約 $40 \%$ 高く, 実効減衰時定数 $\tau_{\text {eff }}$ のほうはシミュレー ション值 $\tau_{\mathrm{eff}} \mathrm{f}^{\prime}$ より $16 \%$ 短いことがわかった。これ ら差異の原因は, 線材・コイル構成材の温度依存性考 慮の仕方にあると考えられる。すなわち，計算機シミ ユレーションでは物性值の温度依存性を厳密に取り大 れている。解析法においては $U(\theta)=\int(\gamma C / \rho) d \theta$ 関数 を通してマク口的に温度依存性を反映していることと 比抵抗 $\rho$ 温度 $\theta$ 比例性を仮定している。したがっ て, $\mathrm{Cu}$ 材の $\rho$ は低温においては小さく, 発熱も少な いのでシミュレーションの $\tau_{\mathrm{eff}} \mathrm{f}^{\prime}$ が解析值より長くな るのは当然である。温度上昇值についていえば，本近 似計算の場合には FRP の $\mathrm{F} C$ (約 $10 \%$ ) を考慮して いないこと, NbTi の $\gamma C$ を（30）式の占積率で近似 計算（約 $10 \%$ 過小評価）していることを考えると 温度依存性考虑の差異に起因する寄与分は 15～20\% 程度と考えられる。計算機シミュレーション值を真值 とすると，本近似計算式は $20 \%$ 程度高いあるいは安 全側の温度上昇值を与えるといえそうである。

\section{2 ホットスポットモデルとの比較}

従来, 本導体のような大容量導体に対してはWilson のホットスポットモデルにより外部抵抗消費のみを考 慮して近似計算していた ((2) 式のケースに対応)。 減衰時間 $T_{\mathrm{d}}$ は外部抵抗回路時定数 $\tau=L / R_{\mathrm{e}}$ の $1 / 2$ で, 本ケースでは $T_{\mathrm{d}}=16.5 / 2=8.25 \mathrm{~s}$ となり, 温度上昇 值 $\theta_{\mathrm{m}} \sim 250 \mathrm{~K}$ が得られる。すなわち, 従来の近似計 算式では本近似計算值 $125 \mathrm{~K}$ の 2 倍という過大な温度 上昇值を与え (シミュレーション值の 2.8 倍), あま りに安全側過ぎると考えられる。したがって，本近似 計算式のほうが計算機シミュレーションに近く，より 妥当な近似解析式といえよう。

\section{3 本近似式の妥当性}

\subsection{1 他の近似式の検討}

外部抵抗消費と自己発熱の両方を考慮した近似式と しては，下記の簡易式が提案されている5

$$
\tau \mathrm{de}^{\prime}=\tau_{\mathrm{eff}^{\prime}} / 2=L / 2\left(R_{\mathrm{i}}+R_{\mathrm{e}}\right)=1 /\left(\frac{1}{T_{\mathrm{Q}}}+\frac{2}{\tau}\right)
$$

上式に $L I_{0}^{2} / 2$ をかけて変形すると下式が得られる。

$$
\begin{aligned}
L I_{0}^{2} / 2 & =\left(L I_{0}^{2} / 2\right)\left(T_{\mathrm{de}^{\prime}} / T_{\mathrm{Q}}+2 T_{\mathrm{de}} / \tau\right) \\
& =I_{0}^{2} R_{\mathrm{i}} T_{\mathrm{de}^{\prime}}+I_{0}^{2} R_{\mathrm{e}} T_{\mathrm{de}^{\prime}}
\end{aligned}
$$

上式は蓄積エネルギーが $T_{\mathrm{de}^{\prime}}$ 時間内に $R_{\mathrm{i}}$ および $R_{\mathrm{e}}$ で消費されるというエネルギーバランスの式であ り, (1) コイル電流 $I=I_{0}$ (一定), (2) $R_{\mathrm{i}}$ 発熱の時間 的比例性 $\left(T_{\mathrm{de}} / T_{\mathrm{Q}}\right)$ が仮定されている。しかし, 実際 には $I$ は指数関数的に減衰し， $R_{\mathrm{i}}$ \& $T^{5}$ で増加して おり時間的比例性は成立しえない。上式の物理的意味 は, $T_{\mathrm{Q}}$ と $\tau / 2$ の調和平均式であり, 単なる簡易式と いえよう。

もし, Wilson の解析法 ( $I=I_{0}$ 一定) を踏襲する なら $R_{\mathrm{i}} \propto T^{5}$ の時間的関係性を考慮して次式の実効減 衰時間 $T_{\mathrm{de}}$ " (Wilson の改良近似式II と呼ぶ) が導か れる。

$$
\begin{aligned}
& L I_{0}^{2} / 2=\left(L I_{0}^{2} / 2\right)\left(T_{\mathrm{de}^{\prime \prime}} / T_{\mathrm{Q}}\right)^{6}+\left(L I_{0}^{2} / 2\right) 2 T_{\mathrm{de}^{\prime \prime}} / \tau \\
& \therefore \quad 1=\left(T_{\mathrm{de}^{\prime \prime}} / T_{\mathrm{Q}}\right)^{6}+2 T_{\mathrm{de}^{\prime \prime}} / \tau
\end{aligned}
$$

上式は， $R_{\mathrm{i}}$ の時間的関倸性 $\left(\propto T^{5}\right)$ を含み，実際 により近くなっているが，電流の指数関数的変化を考 慮していないところが限界である。

\subsection{2 各近似式による実効時間比較}

前記のごとく，本近似式はコイル電流の指数関数的 減衰の実効時定数 $\tau_{\mathrm{eff}}=2 T_{\mathrm{de}}$ を導入することにより, エネルギーバランスの式から自然に求められたもので ある。ここでは, 本近似式と簡略式 (32) 式おょび Wilson の近似式II（34）式を用いて，それぞれ実効 減衰時間 $T_{\mathrm{d}}, T_{\mathrm{d}}{ }^{\prime}$ および $T_{\mathrm{d}}{ }^{\prime \prime}$ を計算し, 相互比較を 試みよう。各式による計算結果を Table 6 に示す。 外部抵抗回路時定数 $\tau=16 \mathrm{~s}$ の場合のみ Fig. 9 に図 示する。

Table 6 および Fig. 9 から (1) Wilson II 式は常 に長いほうへずれ， $T_{\mathrm{Q}}$ が少し長くなる上て/2 に等し くなる。(2) 簡易式は 調和平均のため変化は緩い。(3) 古河式 (本近似式) は $T_{\mathrm{Q}}$ が短い時には $T_{\mathrm{d}}$ はより 短く, $T_{\mathrm{Q}}$ が長くなると $\tau / 2$ に近づく傾向を示すこと がわかる。本近似式は常電導伝搬の影響をよく反映し ており，妥当と考えられる。 
Table 6 Comparison between calculation results by three analytical formulas.

\begin{tabular}{|c|c|c|c|c|c|c|c|c|}
\hline \multirow{2}{*}{$\tau$} & & \multicolumn{7}{|c|}{$T_{\mathrm{Q}}$} \\
\hline & & 5 & 7 & 10 & 15 & 20 & 30 & 50 \\
\hline \multirow{3}{*}{8} & Furukawa $T_{\mathrm{d}}$ & 1.54 & 2.07 & 2.75 & 3.57 & 3. 87 & 3.99 & 4.0 \\
\hline & Simplified $T_{\mathrm{d}^{\prime}}$ & 2.22 & 2.55 & 2.86 & 3.16 & 3.33 & 3.53 & 3. 70 \\
\hline & Wilson II $T_{\mathrm{d}}^{\prime \prime}$ & 3.52 & 3.88 & 3.98 & 4.0 & 4.0 & 4.0 & 4.0 \\
\hline \multirow{3}{*}{16} & Furukawa $T_{\mathrm{d}}$ & 1.61 & 2. 21 & 3.08 & 4. 39 & 5.50 & 7.04 & 7.93 \\
\hline & Simplified $T_{\mathrm{d}^{\prime}}$ & 3.08 & 3.73 & 4. 44 & 5.22 & 5.71 & 6.32 & 6.90 \\
\hline & Wilson II $T_{\mathrm{d}}^{\prime \prime}$ & 4.38 & 5.69 & 7.03 & 7.85 & 7.98 & 8.0 & 8.0 \\
\hline \multirow{3}{*}{32} & Furukawa $T_{\mathrm{d}}$ & 1.64 & 2.28 & 3.22 & 4.72 & 6.16 & 8.78 & 12.8 \\
\hline & Simplified $T_{\mathrm{d}^{\prime}}$ & 3.81 & 4. 87 & 6.15 & 7.74 & 8.89 & 10.4 & 12.1 \\
\hline & Wilson II $T_{\mathrm{d}}{ }^{\prime \prime}$ & 4.72 & 6.42 & 8.76 & 11.9 & 14.1 & 15.7 & 16.0 \\
\hline
\end{tabular}

(Unit: second)

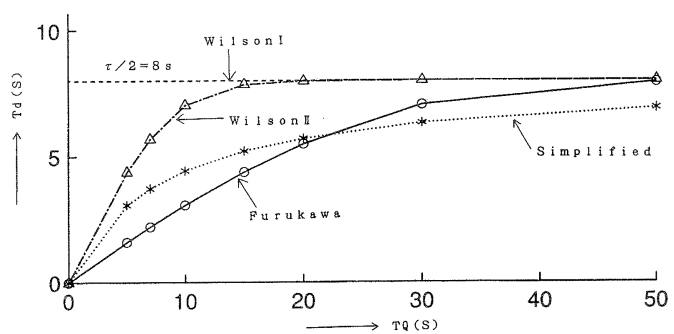

Fig. 9 Decav times calculated by three analytical formulas.

\subsection{3 本近似式の限界}

前節までの議論により, 本近似式の妥当性は裏付け られたといえる。しかし，本近似式にも解析式として の限界がある。6.1節で述べたように各物性值の温度 依存性を厳密汇取り入れることはできないし，常電導 伝搬速度 $v$ も本来電流 $I$ に依存（ $I$ に比例）している のを一定として解析した。計算機シミュレーションの 時, vを電流依存とした場合もシミュレーションして みたが，結果は $\theta_{\mathrm{m}} \sim 90 \mathrm{~K} ， \tau_{\mathrm{eff}}{ }^{\prime} \sim 16 \mathrm{~s}$ とほとんど変 らなかった。因みにvの電流比例性を考慮すると下式 が導かれる。

$$
1=\frac{360 T_{\mathrm{a}} T_{\mathrm{de}}{ }^{5}}{T_{\mathrm{Q}}{ }^{6}}\left(\frac{T_{\mathrm{de}}}{3 T_{\mathrm{de}}+\tau}\right)^{6}+\frac{2 T_{\mathrm{de}}}{\tau}
$$

上式による実效減衰時間は $T_{\mathrm{de}}=t_{\mathrm{eff}} / 2=8.1 \mathrm{~s}$ とv 固定の場合より長くなり (物理的に妥当), 本ヶース ではたまたまシミュレーション值に一致した。いずれ にせよクエンチ点がコイル中央からずれた場合，伝搬 がさらに複雑な場合あるいはより正確性を期す場合に は計算機シミュレーションに頼らざるを得ないことは いうまでもない。

\section{7. 結 論}

大容量導体を用いた中型マグネットに扔けるクエン 于時の導体温度上昇に関して, 新しい近似計算式を導 くとともに計算機シミュレーションおよび従来の近似 式との比較・検討を行った。得られた主な結論は以下 のとおりである。

1）本近似式は，自己発熱と外部抵抗消費の双方を 考虑し，実效減衰時定数を導入してエネルギー平衡的 に求めたもので，物理的により妥当な計算式である。

2）本近似式は, 計算機シミュレーション結果に比 し， $20 \%$ 程度安全側の温度上昇值を与える。

3）Wilson の近似式や簡易式は，本近似式より 2 倍以上過剩安全側の温度上昇值を与える。

4）ただし，本近似式においても各物性值の温度依 存性の厳密な取込みや複雑な伝搬の取扱いには限界が あり,必要により計算機シミュレーションが望ましい。

\section{参 考 文 献}

1) N. M. Wilson: Superconducting Magnet, Clarendon Press (1983) 200

2) 井上 至ら：第 49 回低温工学・超電導学 会 C 3-13(1993)

3) R. F. Broom and E. H. Rhoderick: Brit. J. Appl. Phys. 11 (1960) 292

4) N.M.Wilson: Rutherford Lab. Report RHEL/ M 151 (1968)

5）国際超電導産業技術研究センター：平成 4 年度 超電導電力貯蔵システム要素技術開発に関する 報告書 (第 2 分冊) クエンチ保護の要素技術開 発調查 Chapt. 5 (1993) 52

低温工学 


\section{付 録}

コイルの自己発熱のみを考慮した Wilson の近似式と本近似式を対照して下記に示す。さらに，外部抵抗時定 数のみにより定まるWilson I 式，内部抵抗の時間的関係式を考慮した改良 Wilson II 式扔よび簡易式（ $\tau$ と $T_{Q}$ の調和平均式）を追記する。

(Wilson の特性時間) $\quad T_{\mathrm{Q}}=\left(90 L A^{2} U_{0}^{2} / 4 \pi \alpha^{2} \rho_{0} J_{0}^{4} v^{3}\right)^{1 / 6}$

(各境界にぶつかる時間) $\quad\left\{\begin{array}{l}T_{\mathrm{a}}=a / v, \quad T_{\mathrm{b}}=b / \alpha v, T_{\mathrm{c}}=c / \alpha v \\ t_{\mathrm{a}}=T_{\mathrm{a}} / T_{\mathrm{Q}}, \quad t_{\mathrm{b}}=T_{\mathrm{b}} / T_{\mathrm{Q}}, \quad t_{\mathrm{c}}=T_{\mathrm{c}} / T_{\mathrm{Q}}\end{array}\right.$

\section{Wilson の式}

本近似式

$$
T_{\mathrm{d}}=t_{\mathrm{d}} T_{\mathrm{Q}}
$$

$$
T_{\mathrm{de}}=t_{\mathrm{de}} T_{\mathrm{Q}}
$$

(無制限伝搬) $T_{\mathrm{d}_{0}}=t_{\mathrm{d} 0} T_{\mathrm{Q}}=T_{\mathrm{Q}}$

$$
1=720 t_{\mathrm{de}}{ }^{6}+t_{\mathrm{de}}\left(2 T_{\mathrm{Q}} / \tau\right)
$$

(1 次元制限)

$T_{\mathrm{d}_{1}}=t_{\mathrm{d}_{1}} T_{\mathrm{Q}}=\left(1 / 3 t_{\mathrm{a}}\right)^{1 / 5} T_{\mathrm{Q}}$

$1=360 t_{\mathrm{a}} t_{\mathrm{de}}{ }^{5}+t_{\mathrm{de}}\left(2 T_{\mathrm{Q}} / \tau\right)$

(2 次元制限) $\quad T_{\mathrm{d}_{2}}=t_{\mathrm{d} 2} T_{\mathrm{Q}}=\left(2 / 15 t_{\mathrm{a}} t_{\mathrm{b}}\right)^{1 / 4} T_{\mathrm{Q}} \quad 1=180 t_{\mathrm{a}} t_{\mathrm{b}} t_{\mathrm{de}} \mathrm{e}^{4}\left(1-\frac{\sqrt{t_{\mathrm{a}} t_{\mathrm{b}}}}{3 t_{\mathrm{de}}}\right)+\frac{2 t_{\mathrm{de}} T_{\mathrm{Q}}}{\tau}$

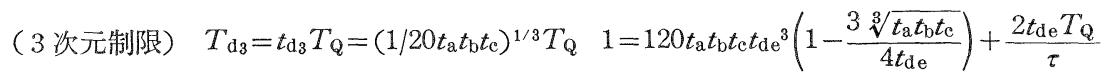

Wilson I の式

$$
T_{\mathrm{d}}=\tau / 2
$$

簡易式

$$
T_{\mathrm{de}}{ }^{\prime}=1 /\left(1 / T_{\mathrm{Q}}+2 / \tau\right)
$$

Wilson $\Pi の$ 式

$$
1=\left(T_{\mathrm{de}^{\prime \prime}} / T_{\mathrm{Q}}\right)^{6}+2 T_{\mathrm{de}^{\prime \prime}} / \tau
$$

